\title{
PERAN INOVASI PRODUK DALAM MEMEDIASI PENGARUH ORIENTASI KEWIRAUSAHAAN TERHADAP KINERJA PEMASARAN UMKM KULINER DI BADUNG
}

\author{
Desak Made Putriasih $^{1}$ I Gusti Ayu Ketut Giantari ${ }^{2}$
}

Article history:

Submitted:

2 Juni 2021

Revised:

10 Juni 2021

Accepted:

10 Juni 2021

\section{Keywords:}

Product Innovation;

Entrepreneurial Orientation;

Marketing Performance.

\section{Kata Kunci:}

Inovasi Produk;

Orientasi Kewirausahaan;

Kinerja Pemasaran.

\section{Koresponding:}

Fakultas Ekonomi dan Bisnis Universitas Udayana, Bali, Indonesia

Email:putriasih123@gmail.com
Abstract

In the current era of globalization, business development, especially in culinary MSMEs, is fast. To face competition requires the ability to innovate in products and improvement in marketing performance. The purpose of this study is to explain role of product innovation in mediating the influence of entrepreneurial orientation on marketing performance. This research was conducted in Badung Regency on the owners or managers of culinary MSMEs. The number of samples in this study were as many as 40 culinary MSMEs using purposive sampling method. Data collection was carried out by distributing questionnaires. The results show that entrepreneurial orientation had a positive but insignificant effect on marketing performance; Entrepreneurial orientation positively and significantly influences product innovation; Product innovation positively and significantly influences marketing performance and product innovation significantly mediates the effect of entrepreneurial orientation on marketing performance.

\begin{tabular}{l} 
Abstrak \\
\hline Di era globalisasi seperti sekarang ini, pembangunan usaha khususnya pada \\
UMKM Kuliner berlangsung cepat. Untuk menghadapi persaingan \\
dibutuhkan kemampuan wirausaha untuk berinovasi dalam produknya serta \\
pengusaha mampu meningkatkan kinerja pemasarannya. Tujuan dari \\
penelitian ini adalah untuk menjelaskan peran inovasi produk dalam \\
memediasi pengaruh orientasi kewirausahaan terhadap kinerja pemasaran. \\
Penelitian ini dilakukan di Kabupaten Badung terhadap pemilik atau \\
pengelola UMKM kuliner. Adapun jumlah sampel dalam penelitian ini \\
adalah sebanyak 40 UMKM kuliner dengan metode purposive sampling. \\
Pengumpulan data dilakukan dengan menyebarkan kuesioner. Hasil \\
penelitian menunjukkan Orientasi kewirausahaan berpengaruh positif tetapi \\
tidak signifikan terhadap kinerja pemasaran; Orientasi kewirausahaan secara \\
positif dan signifikan berpengaruh terhadap inovasi produk; Inovasi produk \\
secara positif dan signifikan berpengaruh terhadap kinerja pemasaran dan \\
Inovasi produk secara signifikan memediasi pengaruh orientasi \\
kewirausahaan terhadap kinerja pemasaran.
\end{tabular}


Peran Inovasi Produk Dalam Memediasi...

Desak Made Putriasih \& I Gusti Ayu Ketut Giantari

\section{PENDAHULUAN}

Perkembangan perekonomian berjalan sangat pesat seiring perkembangan teknologi informasi yang semakin canggih serta tatanan perekonomian dunia yang semakin mengarah pada perdagangan bebas dan tingkat persaingan yang tinggi pada berbagai sektor industri, telah menyebabkan era globalisasi yang kini tidak dapat dihindari bagi setiap kalangan industri. Di era globalisasi seperti sekarang ini, pembangunan usaha khususnya di bidang industri makanan dan minuman berlangsung cepat. Banyak bermunculan usaha - usaha baru khususnya produsen dalam industri makanan dan minuman baik dalam skala kecil, menengah, hingga skala besar. Era globalisasi ini tidak hanya berdampak bagi industri berskala besar saja, namun juga berdampak pada UMKM (Pertiwi \& Siswoyo, 2016).

Usaha Mikro Kecil Menengah (UMKM) memegang peranan yang cukup penting dalam perekonomian di Indonesia. UMKM memiliki proporsi sebesar 99,99\% dari total keseluruhan pelaku usaha di Indonesia atau sebanyak 56,54 juta unit (LPPI dan Bank Indonesia, 2015). Menurut Menteri Negara Koperasi dan Usaha Kecil Menengah (Menegkop dan UKM), bahwa yang dimaksud Usaha Kecil (UK), termasuk Usaha Mikro (UMI) adalah usaha yang mempunyai kekayaan bersih paling banyak 200 juta rupiah, tidak termasuk tanah dan bangunan tempat usaha, dan memiliki penjualan tahunan paling banyak 1 milyar rupiah. Pasca krisis tahun 1997 hingga tahun 1998 Usaha Mikro, Kecil dan Menengah (UMKM) berkontribusi besar dengan menjaga kestabilan ekonomi, diakibatkan UMKM memiliki kemampuan beradaptasi dari goncangan ekonomi dengan pembukaan lapangan pekerjaan dan pemerataan pendapatan (Nursini, 2020)

Provinsi Bali merupakan suatu provinsi di Indonesia dimana warganya banyak yang berkecimpung dalam dunia bisnis UKM. Dinas Perindustrian dan Perdagangan Provinsi Bali (2019), pada tahun 2019 terdapat 15.884 unit industri UKM yang menyerap tenaga kerja sebanyak 104.417 orang. Bali masih merupakan favorit destinasi bagi wisatawan mancanegara, jumlah wisatawan yang masuk melalui Bandara I Gusti Ngurah Rai jumlahnya mencapai 6.239.543 wisatawan, jumlah ini lebih banyak jika dibandingkan dengan jumlah wisatawan yang berkunjung ke Ibukota Negara Indonesia yaitu Jakarta. Sebagian besar wisatawan yang datang melakukan transaksi (pengeluaran) terhadap 13 jenis pengeluaran utama, dan salah satunya merupakan pengeluarannya terhadap makanan (Badan Pusat Statistik, 2019). Hal ini menjadi peluang besar bagi usaha pada sektor makanan di mana wisatawan menjadi konsumen pada usaha ini.

Keberadaan UMKM ini menurut Badan Pusat Statistik (BPS) dapat diklasifikasikan menjadi 2 kelompok industri yaitu Industri Mikro Kecil (IMK) serta Industri Besar Sedang (IBS). Klasifikasi industri ini dibagi hanya berdasarkan jumlah tenaga kerja yang digunakan tanpa melihat apakah perusahaan menggunakan mesin maupun dari jumlah modal yang dimiliki perusahaan, dimana industri mikro mencakup 1-4 orang tenaga kerja, industri kecil 5-19 
Peran Inovasi Produk Dalam Memediasi...

Desak Made Putriasih \& I Gusti Ayu Ketut Giantari

orang tenaga keja, industri sedang 20-99 orang tenaga kerja dan industri besar lebih dari 100 orang. Besarnya jumlah IMK di Indonesia jauh lebih tinggi dibandingkan dengan perusahaan yang bergerak pada IBS, khususnya pada sektor industri makanan yang menembus angka 1,167,541 usaha IMK daripada IBS yang hanya mencapai. 5,852 pada 2013 lalu.

Perkembangan pariwisata di Bali sebagai salah satu destinasi andalan di Indonesia medorong perkembangan peluang jumlah UMKM dikarenakan popularitas Bali mengakibatkan tingkat wisatawan baik dari dalam maupun luar negeri menjadi konsumen yang potensial dalam perkembangan UMKM. Pembukaan peluang dan pengembangan pasar dapat menjadi stimulus untuk pengembangan minat berwisausaha.

Untuk menghadapi persaingan dalam sektor industri makanan, pemilik usaha haruslah memiliki keunikan dan keunggulan dibandingkan produk pesaing sejenis dengan cara berinovasi terhadap produknya. Inovatif merupakan sikap dari seorang wirausahawan (entrepreneur) yang mengacu pada suatu sikap wirausahawan untuk terlibat secara kreatif dalam proses percobaan terhadap gagasan baru yang memungkinkan wirausahawan menghasilkan produk atau jasa baru, baik untuk pasar sekarang maupun ke pasar baru (Fatoki, 2017). Utaminingsih (2016) menyatakan permasalahan yang dihadapi UMKM adalah rendahnya produktivitas pada penciptaan produk baru akibat kurangnya daya kreativitas dan inovatif sehingga kinerja pemasaran tidak berjalan dengan stabil. Konsep kinerja pemasaran didukung dengan banyak faktor mulai dari kesadaran akan pandangan terhadap pasar, kesadaran melakukan strategi yang inovatif, kemampuan untuk mengambil risiko dan orientasi dari proses pembelajaran

Kinerja pemasaran adalah sesuatu yang digunakan untuk mengukur keberhasilan strategi yang digunakan perusahaan dalam memasarkan produknya di pasar. Kinerja pemasaran adalah hasil dari keseluruhan baik itu usaha, strategi, maupun kinerja yang telah dijalankan oleh suatu perusahaan. Kinerja pemasaran merupakan ukuran prestasi yang diperoleh dari akivitas proses pemasaran secara menyeluruh dari sebuah perusahaan atau organisasi. Usaha dalam berinovasi terhadap suatu produk dipercaya mampu meningkatkan kinerja pemasaran. Kinerja pemasaran juga dipandang sebagai suatu konsep untuk mengukur prestasi pasar yang telah dicapai oleh suatu produk yang dihasilkan perusahaan.

Orientasi kewirausahaan merupakan proses, praktek dan aktifitas yang mendorong tumbuhnya sikap kewirausahaan (Pramesti \& Giantari, 2016). Kewirausahaan didefinisikan secara umum sebagai mengidentifikasi dan menerapkan peluang. Dimensi kunci yang menjadi ciri orientasi kewirausahaan mencakup kecenderungan untuk bertindak secara otonom, kemauan untuk berinovasi dan mengambil risiko, dan kecenderungan untuk menjadi agresif terhadap pesaing dan relatif proaktif untuk peluang pasar, mengejar peluang baru secara inovatif, berani mengambil risiko dan secara proaktif berhubungan erat dengan konsep orientasi kewirausahaan (Djayadiningrat dkk, 2017).

Inovasi produk dianggap penting dalam penelitian yang dilakukan oleh (Back 
et al., 2018). Inovasi terhadap suatu produk berpotensi meningkatkan nilai perusahaan di mata konsumen dan inovasi terhadap produk merupakan kunci keberhasilan suatu perusahaan dalam bertahan pada ketatnya persaingan. Inovasi adalah sebuah terobosan baru yang dilakukan untuk mengembangkan produk ataupun membuat produk baru dalam rangka mendapatkan segmen pasar baru. Inovasi yang dilakukan pada perusahaan dipercaya mampu meningkatkan kinerja perusahaan

Berdasarkan pra survei yang dilakukan pada lima UMKM kuliner di Kabupaten Badung yang telah memenuhi kriteria responden yaitu berlokasi di Kabupaten Badung dan sudah beroperasi minimal enam bulan saat penelitian ini dilakukan. Responden menyatakan berani mengambil risiko dalam berbisnis, mampu beradaptasi dan memanfaatkan peluang yang ada serta memiliki sikap tanggap dalam merespon pasar. Orientasi kewirausahaan yang meningkat mampu meningkatkan inovasi. Pernyataan ini didukung dengan adanya penelitian yang dilakukan oleh Tresna \& Raharja (2019) menemukan bahwa orientasi kewirausahaan berpengaruh positif dan signifikan terhadap kemampuan inovasi perusahaan. Wibisono et al., (2020) menyatakan bahwa terdapat dampak positif dan signifikan dari inovasi produk terhadap kinerja pemasaran, yang berarti bahwa semakin tinggi inovasi produk dari perusahaan di industri kreatif maka akan semakin tinggi pula tingkat kinerja pemasaran. Orientasi kewirausahaan terhadap kinerja perusahaan mampu dimediasi oleh inovasi. Pernyataan ini didukung dengan adanya penelitian yang dilakukan oleh Devara \& Sulistyawati (2019) yang menyatakan bahwa orientasi kewirausahaan terhadap kinerja perusahaan dalam industri kreatif mampu dimediasi oleh inovasi.

Tujuan penelitian ini adalah untuk menjelaskan peran inovasi produk dalam memediasi pengaruh orientasi kewirausahaan terhadap kinerja pemasaran pada UMKM kuliner di Kabupaten Badung. Berdasarkan hubungan inovasi produk memediasi orientasi kewirausahaan terhadap kinerja pemasaran, maka dapat disusun kerangka konseptual sebagaimana pada Gambar 1.

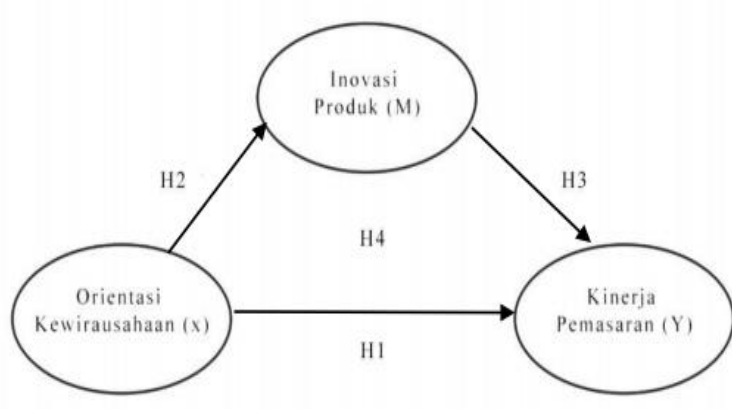

Gambar 1.

Kerangka Konseptual Penelitian

Pada penelitian yang dilakukan oleh Rezaei \& Ortt (2018) menyatakan bahwa orientasi kewirausahaan berpengaruh positif dan signfikan terhadap kinerja pemasaran. Santra (2018) menyatakan bahwa orientasi kewirausahaan berpengaruh positif dan sigifikan terhadap kinerja UKM, karena perlu dimiliki keyakinan bahwa keberhasilan pada suatu usaha dikarenakan rasa percaya akan diri yang tinggi dan keterbukaan untuk dapat meningkatkan penjualan. Penelitian yang dilakukan Wibisono et al., (2020) menunjukan hasil signifikan antara orientasi 
kewirausahaan terhadap kinerja pemasaran, dalam penelitiannya ditegaskan bahwa kinerja pemasaran suatu perusahaan bergantung pada orientasi kewirausahaan. Berdasarkan kajian empiris dari hasil penelitian sebelumnya, dapat dibangun hipotesis adalah sebagai berikut:

$\mathrm{H}_{1}$ : Orientasi kewirausahaan berpengaruh positif dan signifikan terhadap kinerja pemasaran.

Tresna \& Raharja (2019) dan Okangi (2019) menemukan bahwa orientasi kewirausahaan berpengaruh positif dan signifikan terhadap kemampuan inovasi perusahaan serta mampu berdampak positif bagi pertumbuhan ekonomi suatu negara, khususnya bagi negara-negara berkembang. Terdapat hubungan positif dan signifikan antara orientasi kewirausahaan terhadap kemampuan inovasi pada penelitian yang dilakukan Soekotjo et al., (2021) menemukan bahwa orientasi kewirausahaan dengan ketiga aspek yaitu risk taking, proaktif, dan inovatif signifikan sebagai penggerak inovasi, karena ketiga aspek tersebut dianggap mampu berkolaborasi dengan inovasi dalam menciptakan peluang yang unik untuk kelangsungan hidup dan pertumbuhan perusahaan. Berdasarkan kajian empiris dari hasil penelitian sebelumnya, dapat dibangun hipotesis adalah sebagai berikut:

$\mathrm{H}_{2}$ : Orientasi kewirausahaan berpengaruh positif dan signifikan terhadap inovasi produk.

Pada penelitian yang dilakukan oleh Efrata et al., (2019) menyatakan bahwa terdapat dampak positif dan signifikan dari inovasi produk terhadap kinerja pemasaran, yang berarti bahwa semakin tinggi inovasi produk dari perusahaan di industri kreatif maka akan semakin tinggi pula tingkat kinerja pemasaran. Berdasarkan penelitian sebelumnya yang dilakukan oleh Lapian et al., (2016); Pramesti \& Giantari (2016) mendapatkan hasil bahwa pengaruh inovasi berpengaruh positif dan signifikan terhadap kinerja pemasaran. Berdasarkan kajian empiris dari hasil penelitian yang ada maka dapat dibangun atau disusun hipotesis sebagai berikut:

$\mathrm{H}_{3}$ : Inovasi produk berpengaruh positif dan signifikan terhadapkinerja pemasaran.

Ryiadi \& Yasa (2016) yang menyatakan bahwa pada uji hipotesis yang dilakukan pada peran kemampuan inovasi memediasi pengaruh orientasi kewirausahaan terhadap kinerja produk, hal ini berarti orientasi kewirausahaan mampu meningkatkan kemampuan inovasi seorang wirausahawan serta mampu meningkatkan kinerja produk yang akan dihasilkan. Sulaeman (2018) menemukan bahwa orientasi kewirausahaan terhadap kinerja perusahaan dalam industri kreatif mampu dimediasi oleh inovasi. Putra \& Setiawan (2019) dalam penelitiannya menemukan bahwa inovasi memediasi hubungan antara orientasi kewirausahaan, sumber daya perusahaan, usaha kecil menengah Branding terhadap kinerja perusahaan, penelitian ini dilakukan pada usaha kecil menengah. Berdasarkan kajian empiris dari hasil penelitian sebelumnya, dapat dibangun hipotesis adalah sebagai berikut:

$\mathrm{H}_{4}$ : Inovasi produk mampu memediasi pengaruh orientasi kewirausahaan terhadap kinerja pemasaran. 
Peran Inovasi Produk Dalam Memediasi...

Desak Made Putriasih \& I Gusti Ayu Ketut Giantari

\section{METODE PENELITIAN}

Penelitian ini merupakan jenis penelitian asosiatif dengan pendekatan kuantitatif. Dipilihnya Kabupaten Badung sebagai lokasi penelitian karena Kabupaten Badung merupakan daerah yang berada di Provinsi Bali yang memiliki tempat wisata utama di Pulau Bali. UMKM Kuliner merupakan salah satu sektor pendukung pariwisata yang mendorong perekonomian kabupaten Badung, menjadikan alasan dipilihnya Kabupaten Badung. Subjek dalam penelitian ini adalah pemilik atau pengelola UMKM kuliner di Kabupaten Badung. Penelitian dilakukan selama 1 bulan dari Maret hingga April tahun 2020. Adapun Objek dalam penelitian ini adalah orientasi kewirausahaan, kinerja pemasaran, dan inovasi produk pada UMKM kuliner di Kabupaten Badung.

Orientasi kewirausahaan UMKM Kuliner merupakan strategi perusahaan dalam meningkatkan kinerja UMKM Kuliner tersebut. Dimensi kunci yang menjadi ciri orientasi kewirausahaan mencakup kecenderungan untuk bertindak secara otonom, kemauan untuk berinovasi dan mengambil risiko, dan kecenderungan untuk menjadi agresif terhadap pesaing dan relatif proaktif untuk peluang pasar, mengejar peluang baru secara inovatif, berani mengambil risiko dan secara proaktif berhubungan erat dengan konsep orientasi kewirausahaan. Empat indikator orientasi kewirausahaan yang diadaptasi dari penelitian Ibrahim \& Mahmood (2016) maka didapat indikator dalam mengukur orientasi kewirausahaan: 1) Mengambil risiko, didefinisikan sebagai seorang yang berorientasi pada peluang dalam ketidakpastian pengambilan keputusan; 2) Proaktif adalah kemampuan pemimpin untuk mengenali peluang dan komitmen terhadap inovasi; 3) Antisipatif adalah kemampuan perusahaan mengantisipasi segala kejadian yang mungkin terjadi terhadap segala perubahan; 4) Pencarian target pasar baru adalah perusahaan selalu berusaha mencari dan memperluas target pasar dan pelanggan baru.

Inovasi produk UMKM kuliner merupakan kemampuan perusahaan dalam mengemas produk agar memiliki keunikan dan keunggulan dibandingkan pesaing serta memberikan posisi yang unik bagi perusahaan tersebut di pasar. Indikator dalam pengukuran variabel inovasi produk Ejdys (2016) adalah sebagai berikut: 1) Packaging desain produk adalah kemampuan perusahaan dalam mengemas produk agar memiliki keunikan dan keunggulan dibandingkan pesaing; 2) Penambahan varian produk adalah kemampuan perusahaan untuk menciptakan serta mengembangkan produk baru yang disesuaikan dengan keinginan pelanggan; 3) Perusahaan selalu mengontrol kualitas pada produk yang dihasilkan; 4) Pengembangan kualitas adalah perusahaan secara aktif melakukan pengembangan atas kualitas produknya.

Kinerja pemasaran UMKM kuliner merupakan pencapaian atau prestasi yang dapat diraih oleh perusahaan dalam periode waktu tertentu. Kinerja pemasaran merupakan faktor yang digunakan untuk mengukur dampak dari strategi yang diterapkan oleh perusahaan dipandang dari aspek 
Peran Inovasi Produk Dalam Memediasi...

Desak Made Putriasih \& I Gusti Ayu Ketut Giantari

pemasarannya. Kinerja pemasaran juga merupakan konsep yang digunakan untuk mengukur sejauhmana prestasi pasar yang telah dicapai oleh produk pada suatu perusahaan. Indikator dalam variabel kinerja pemasaran diadaptasi dari Rezaei \& Ortt (2018) adalah sebagai berikut: 1) Pertumbuhan laba adalah perubahan persentase kenaikan laba yang diperoleh perusahaan; 2) Pertumbuhan penjualan adalah sejumlah angka penjualan yang meningkat dari periode sebelumnya; 3) Jangkauan wilayah pemasaran adalah meluasnya jangkauan wilayah suatu pemasaran produk perusahaan. 4) Pertumbuhan pelanggan adalah tingkat pertumbuhan pelanggan perusahaan.

Sumber primer diperoleh melalui kuesioner terhadap pemilik atau pengelola UMKM kuliner di Kabupaten Badung. Sumber sekunder diperoleh dari bahan bacaan melalui teori - teori yang berkaitan dengan variabel penelitian yang dikutip terkait dengan topik penelitian, baik melalui website, jurnal, institusi pemerintahan serta pihak lain yang mempublikasikan data. Penelitian ini menggunakan kuesioner sebagai alat pengumpul data, sehingga perlu dilakukan pengujian validitas dan reliabiltas agar kuesioner layak untuk digunakan. Populasi dalam penelitian ini adalah pemilik atau pengelola UMKM kuliner yang berlokasi di Kabupaten Badung. Dalam penelitian ini sampel yang digunakan adalah 40 sampel pemilik atau pengelola UMKM kuliner di Kabupaten Badung. Ukuran sampel ini sudah representatif karena masih dalam rentang 30500 sampel yang merupakan rentang kelayakan sampel
Metode penentuan sampel yang digunakan pada penelitin ini adalah non probability sampling dengan metode purposive sampling, yakni sampel ditentukan dengan pertimbangan yaitu 1). Responden yang telah menyelesaikan tingkat pendidikan terakhir minimal SMA/SMK sederajat dengan pertimbangan bahwa seseorang pada jenjang pendidikan minimal SMA/SMK dapat memahami dan mengerti isi dari kuesioner; 2). Responden merupakan pemilik atau pengelola UMKM Kuliner di Kabupaten Badung; 3). Minimal telah beroperasi selama 6 bulan; 4). serta sesuai dengan kriteria UMKM berdasarkan UU pasal 6 nomor 20 tahun 2008 yang memiliki kekayaan bersih paling sedikit Rp50.000.000,00 (lima puluh juta rupiah) sampai dengan paling banyak Rp10.000.000.000,00 (sepuluh milyar rupiah) tidak termasuk tanah dan bangunan tempat usaha; atau memiliki hasil penjualan tahunan lebih dari Rp2.500.000.000,00 (dua milyar lima ratus juta rupiah) sampai dengan paling banyak Rp50.000.000.000,00 (lima puluh milyar rupiah).

Berdasarkan kriteria tersebut maka ukuran sampel yang digunakan dalam penelitian ini adalah sebanyak 40 sampel berupa pengelola UMKM kuliner di Kabupaten Badung. Data dalam penelitian ini dikumpulkan melalui instrumen penelitian berupa kuesioner. Kuesioner terdiri atas pernyataan terbuka dan tertutup. Pernyataan terbuka meliputi nama responden, usia responden, jenis kelamin, nama usaha dan alamat usaha. Pernyataan tertutup merupakan peryataan yang telah dan diberikan pilihan jawabannya. Pernyataan tertutup diukur menggunakan Skala Likert dengan skala 1 
sampai 5. Teknik analisis data yang digunakan adalah analisis jalur.

\section{HASIL DAN PEMBAHASAN}

Perekonomian secara terus menerus mengalami pertumbuhan dan perubahan yang semakin terbuka pesat sehingga membuat persaingan semakin ketat. Salah satu industri yang mengalami perkembangan cukup pesat adalah jenis industri kuliner/makanan yang berpotensi besar untuk terus tumbuh dan berkembang. UMKM kuliner ini mampu bertahan dalam keadaan apapun, termasuk saat krisis perekonomian sekalipun.

Data yang diperoleh dari Dinas Perindustrian dan Perdagangan Provinsi Bali pada tahun 2019 terdapat 15.884 unit industri UKM yang menyerap tenaga kerja sebanyak 104.417 orang, pertumbuhan UMKM kuliner/makanan dari tahun ketahun menunjukan pertumbuhan yang positif, sektor kuliner yang dikembangkan dalam Usaha Mikro Kecil dan Menengah (UMKM) merupakan industri yang potensial mengingat kecenderungan pola konsumsi masyarakat mengarah pada konsumsi produk makanan olahan. Terobosan Inovasi Produk kuliner sangat dibutuhkan untuk memberikan daya pembeda dan ciri pada produk yang dihasilkan.

Usaha Mikro Kecil dan Menengah (UMKM) memiliki kontribusi besar dalam meningkatkan pertumbuhan perekonomian di Kabupaten Badung. Kinerja positif yang terus ditunjukan oleh UMKM membuka peluang semakin berdaya saing untuk mencapai Kinerja Pemasaran yang unggul, seiring dengan berkembangnya kebutuhan dan keinginan pelanggan, pengusaha kuliner harus menghasilkan inovasi produk yang selalu terjaga, dan memberikan pelayanan maksimal terhadap pelanggan, memahami dan bersikap responsif terhadap kebutuhan pasar, dan memahami strategi pemasaran yang diarahkan untuk menghasilkan Kinerja Pemasaran yang maksimal.

Karakteristik responden merupakan data responden yang dikumpulkan untuk mengetahui profil responden penelitian. Dalam penelitian ini terdapat sebanyak 40 responden. Berikut merupakan karakteristik keseluruhan profil responden terdiri atas nama, jenis kelamin, usia, dan pendidikan terakhir. Hasil karakteristik responden didominasi oleh laki-laki dengan presentase responden laki-laki sebanyak 55 persen. Karakteristik usia didominasi oleh responden pada rentang usia 20 tahun hingga 24 tahun dengan presentase sebanyak $37.5 \%$. Berdasarkan karakteristik responden bagian pendidikan terakhir, responden dengan jenjang pendidikan terakhir Sekolah Menengah Atas (SMA) merupakan responden terbanyak yaitu 50\%, sedangkan responden dengan pendidikan terakhir sarjana sebanyak $30 \%$.

Uji validitas dilakukan untuk mengetahui bahwa instrumen penelitian yang digunakan, yaitu kuesioner valid untuk mengumpulkan data penelitian. Pengujian dilakukan dengan korelasi pearson untuk menguji apakah instrumen yang digunakan valid atau tidak. 
Tabel 1.

\section{Hasil Uji Validitas Instrumen Penelitian}

\begin{tabular}{|c|c|c|c|}
\hline Variabel & Indikator & $\mathbf{r}_{\text {hitung }}$ & Sig \\
\hline \multirow{5}{*}{$\begin{array}{l}\text { Orientasi } \\
\text { Kewirausahaan } \\
\text { (X) }\end{array}$} & Keberanian & 0.512 & 0.000 \\
\hline & Risiko $\left(\mathrm{X}_{1}\right)$ & & \\
\hline & $\begin{array}{l}\text { Sifat Proaktif } \\
\left(\mathrm{X}_{2}\right)\end{array}$ & 0.688 & 0.000 \\
\hline & Antisiatif $\left(\mathrm{X}_{3}\right)$ & 0.670 & 0.000 \\
\hline & $\begin{array}{c}\text { Pencarian } \\
\text { Target Pasar } \\
\text { Baru }\left(\mathrm{X}_{4}\right)\end{array}$ & 0.612 & 0.000 \\
\hline \multirow[t]{3}{*}{$\begin{array}{l}\text { Inovasi Produk } \\
\text { (M) }\end{array}$} & $\begin{array}{c}\text { Packing Desain } \\
\text { Produk }\left(\mathrm{M}_{1}\right)\end{array}$ & 0.805 & 0.000 \\
\hline & $\begin{array}{c}\text { Penambahan } \\
\text { Varian Produk } \\
\left(\mathrm{M}_{2}\right)\end{array}$ & 0.933 & 0.000 \\
\hline & $\begin{array}{c}\text { Pengembangan } \\
\text { Kualitas }\left(\mathrm{M}_{3}\right)\end{array}$ & 0.889 & 0.000 \\
\hline \multirow[t]{4}{*}{$\begin{array}{l}\text { Kinerja } \\
\text { Pemasaran }(\mathrm{Y})\end{array}$} & $\begin{array}{c}\text { Pertumbuhan } \\
\text { laba }\left(\mathrm{Y}_{1}\right)\end{array}$ & 0.814 & 0.000 \\
\hline & $\begin{array}{c}\text { Pertumbuhan } \\
\text { Penjualan }\left(\mathrm{Y}_{2}\right)\end{array}$ & 0.899 & 0.000 \\
\hline & $\begin{array}{c}\text { Jangkauan } \\
\text { Wilayah } \\
\text { Pemasaran }\left(\mathrm{Y}_{3}\right) \\
\end{array}$ & 0.819 & 0.000 \\
\hline & $\begin{array}{c}\text { Pertumbuhan } \\
\text { Pelanggan }\left(\mathrm{Y}_{4}\right)\end{array}$ & 0.837 & 0.000 \\
\hline
\end{tabular}

Sumber: data diolah, 2020

Pada Tabel 1 menunjukan hasil uji validitas terhadap instrumen penelitian. Hasil perhitungan menunjukan bahwa ketiga variabel memiliki koefisien korelasi lebih besar dari 0,3 sehingga masing-masing indikator dalam kuesioner penelitian ini dianggap valid dan memenuhi syarat validitas data.

Tabel 2.

Hasil Uji Reliabilitas Instrumen Penelitian

\begin{tabular}{lll}
\hline Variabel & $\begin{array}{l}\text { Nilai } \\
\text { Alpha }\end{array}$ & Cronbach's \\
\hline $\begin{array}{l}\text { Orientasi } \\
\text { Kewirausahaan }\end{array}$ & 0.863 \\
\hline Inovasi Produk & 0.848 \\
\hline Kinerja Pemasaran & 0.856 \\
\hline
\end{tabular}

Sumber: data diolah, 2020

Uji reliabilitas dilakukan dengan tujuan untuk mengetahui konsistensi dari alat ukur yang digunakan untuk penelitian. Pada Tabel 2 menunjukan hasil uji reliabilitas instrumen penelitian. Hasil uji menunjukan ketiga variabel memiliki nilai Cronbach's Alpha lebih dari 0,60 sehingga masing masing instrument pernyataan dalam kuesioner penelitian ini dianggap reliabel konsisten sebagai alat ukur penelitian.

Tabel 3.

Deskripsi Penilaian Responden Terhadap Variabel Orientasi Kewirausahaan

\begin{tabular}{|c|c|c|c|c|c|c|c|c|}
\hline \multirow[t]{2}{*}{ Indikator } & \multicolumn{5}{|c|}{ Skor Jawaban } & \multirow[t]{2}{*}{ Jumlah Skor } & \multirow[t]{2}{*}{ Rata-Rata } & \multirow[t]{2}{*}{ Keterangan } \\
\hline & STS & TS & $\mathbf{N}$ & $\mathbf{S}$ & SS & & & \\
\hline $\begin{array}{l}\text { Berani mengambil } \\
\text { risiko kegagalan }\end{array}$ & 0 & 0 & 3 & 10 & 27 & 184 & 4,6 & Sangat Baik \\
\hline $\begin{array}{l}\text { Mampu beradaptasi dan } \\
\text { memanfaatkan peluang } \\
\text { yang ada }\end{array}$ & 0 & 0 & 1 & 19 & 20 & 179 & 4,4 & Sangat Baik \\
\hline $\begin{array}{l}\text { Memiliki sikap tanggap } \\
\text { dalam merespon pasar }\end{array}$ & 0 & 0 & 0 & 17 & 23 & 183 & 4,5 & Sangat Baik \\
\hline $\begin{array}{l}\text { Mampu menciptakan target } \\
\text { pasar yang baru }\end{array}$ & 0 & 0 & 0 & 15 & 25 & 185 & 4,6 & Sangat Baik \\
\hline \multicolumn{6}{|c|}{ Rata-rata skor orientaasi kewirausahaan } & \multicolumn{2}{|r|}{4,525} & Sangat Baik \\
\hline
\end{tabular}


Peran Inovasi Produk Dalam Memediasi... Desak Made Putriasih \& I Gusti Ayu Ketut Giantari

Orientasi kewirausahaan merupakan variabel bebas dalam penelitian ini. Untuk mengukur variabel ini, terdapat empat pernyataan. Tabel 3 menunjukan penilaian responden secara terperinci terhadap variabel orientasi kewirausahaan. Secara keseluruhan penilaian responden terhadap variabel orientasi kewirausahaan adalah sangat baik. Hal tersebut dapat dilihat berdasarkan skor rata-rata sebesar 4,525, dimana skor tersebut masuk kedalam interval sangat baik.
Inovasi produk dalam penelitian ini merupakan variabel terikat. Terdapat 3 pernyataan yang diajukan kepada responden untuk mengukur variabel tersebut. Berdasarkan Tabel 4 secara keseluruhan penilaian responden terhadap variabel inovasi produk adalah sangat baik. Hal tersebut dapat dilihat berdasarkan skor rata-rata sebesar 4,5, dimana skor tersebut masuk kedalam interval sangat baik.

Tabel 4.

Deskripsi Penilaian Responden Terhadap Variabel Inovasi Produk

\begin{tabular}{|c|c|c|c|c|c|c|c|c|}
\hline \multirow[t]{2}{*}{ Indikator } & \multicolumn{5}{|c|}{ Skor Jawaban } & \multirow[t]{2}{*}{ Jumlah Skor } & \multirow[t]{2}{*}{ Rata-Rata } & \multirow[t]{2}{*}{ Keterangan } \\
\hline & STS & TS & $\mathbf{N}$ & $\mathbf{S}$ & SS & & & \\
\hline $\begin{array}{l}\text { Melakukan perubahan } \\
\text { packaging desain seiring } \\
\text { perkembangan mode yang } \\
\text { sejalan }\end{array}$ & 0 & 1 & 7 & 14 & 18 & 169 & 4,2 & Sangat Baik \\
\hline $\begin{array}{l}\text { Berusaha mengembangkan } \\
\text { varian produk } \\
\text { sehingga tetap laku di pasar }\end{array}$ & 0 & 0 & 2 & 11 & 27 & 185 & 4,6 & Sangat Baik \\
\hline $\begin{array}{l}\text { Berberusaha untuk } \\
\text { mengembangkan kualitas } \\
\text { produk }\end{array}$ & 0 & 0 & 0 & 11 & 29 & 189 & 4,7 & Sangat Baik \\
\hline Rata-rata skor inovasi produk & & & & & & & 4,5 & Sangat Baik \\
\hline
\end{tabular}

Sumber: data diolah, 2020

Tabel 5.

Deskripsi Penilaian Responden Terhadap Variabel Kinerja Pemasaran

\begin{tabular}{|c|c|c|c|c|c|c|c|c|}
\hline \multirow[t]{2}{*}{ Indikator } & \multicolumn{5}{|c|}{ Skor Jawaban } & \multirow[t]{2}{*}{ Jumlah Skor } & \multirow[t]{2}{*}{ Rata-Rata } & \multirow[t]{2}{*}{ Keterangan } \\
\hline & STS & TS & $\mathbf{N}$ & $\mathbf{S}$ & SS & & & \\
\hline $\begin{array}{l}\text { Pertumubuhan laba berhasil } \\
\text { memenuhi target } \\
\text { bulannya }\end{array}$ & 0 & 0 & 22 & 18 & 8 & 178 & 4,4 & Sangat Baik \\
\hline $\begin{array}{lr}\text { Pertumbuhan } & \begin{array}{r}\text { penjualan } \\
\text { selalu }\end{array} \\
\begin{array}{l}\text { mengalami } \\
\text { peningkatan } \\
\text { diharapkan }\end{array} & \text { sesuai yang } \\
\end{array}$ & 0 & 1 & 10 & 21 & 8 & 156 & 3,9 & Baik \\
\hline $\begin{array}{l}\text { Selalu berusaha memperluas } \\
\text { jangkauan } \\
\text { pemasaran dengan promosi }\end{array}$ & 0 & 0 & 4 & 14 & 22 & 178 & 4,4 & Sangat Baik \\
\hline $\begin{array}{l}\text { Berhasil meningkatkan } \\
\text { pertumbuhan pelanggan }\end{array}$ & 0 & 1 & 0 & 10 & 29 & 187 & 4,6 & Sangat Baik \\
\hline Rata-rata skor kinerja pemasar & & & & & & & 4,325 & Sangat Baik \\
\hline
\end{tabular}

Sumber: data diolah, 2020 
Dalam penelitian ini, kinerja pemasaran merupakan variabel terikat, dimana terdapat 4 pernyataan yang diukur. Secara lebih terperinci, hasil penilaian responden mengenai variabel kinerja pemasaran dipaparkan pada Tabel 5 . Berdasarkan Tabel 5 secara keseluruhan penilaian responden terhadap variabel kinerja pemasaran adalah sangat baik. Hal tersebut dapat dilihat berdasarkan skor rata-rata sebesar 4,325, dimana skor tersebut masuk kedalam interval sangat baik.

Uji normalitas bertujuan untuk menguji apakah dalam residual dari model regresi yang dibuat berdistribusi normal atau tidak. Uji normalitas dilakukan menggunakan statistik Kolmogorov-Smirnov dimana data dinyatakan berdistribusi secara normal apabila koefisien Asymp.Sig (2-tailed) lebih besar dari 0,05 $(\alpha=5 \%)$. Hasil pengujian uji normalitas disajikan pada Tabel 6.

Tabel 6.

Hasil Uji Normalitas

\begin{tabular}{lc}
\hline & $\begin{array}{c}\text { Asymp. Sig. (2- } \\
\text { tailed) }\end{array}$ \\
\hline Orientasi Kewirausahaan & 0.894 \\
\hline
\end{tabular}

Sumber: data diolah, 2020

$\begin{array}{ccr}\text { Berdasarkan Tabel } & \text { pengujian } \\ \text { terhadap } & \text { unstandardized } & \text { residual }\end{array}$ menghasilkan asymptotic significance lebih besar dari 0,05. Sesuai kaidah pengujian maka dapat disimpulkan bahwa data berdistribusi normal.

Uji multikoleniaritas bertujuan untuk menguji apakah pada model regresi ditemukan adanya korelasi antar variabel bebas. Uji multikoleniaritas dapat dilihat dari tingkat tolerance yang lebih besar dari 10 persen $(0,10)$ atau VIF yang lebih kecil dari 10. Berdasarkan Tabel 8 dapat diketahui bahwa hasil perhitungan tolerance menunjukkan tidak ada variabel independen yang memiliki nilai tolerance $\leq 0,10$ dan nilai $\mathrm{VIF} \geq 10$ yang berarti bahwa tidak ada multikolinieritas antar variabel independen dalam model regresi.

Tabel 7.

Hasil Uji Multikoleniaritas

\begin{tabular}{llcc}
\hline & \multicolumn{2}{c}{ Collinearity Statistics } \\
\cline { 2 - 3 } Model & \multicolumn{2}{c}{ Tolerance } & VIF \\
\hline 1 & & \\
\cline { 2 - 3 } & Orientasi & \\
Kewirausahaan & .830 & 1.205 \\
\cline { 2 - 3 } Inovasi Produk & & \\
\hline
\end{tabular}

Sumber: data diolah, 2020

Uji heteroskedastisitas bertujuan untuk menguji apakah dalam model regresi terjadi ketidaksamaan varian dari residual satu pengamatan ke pengamatan yang lain. Hal ini dapat dilihat pada nilai signifikansi lebih dari 0,05, maka data tersebut dinyatakan tidak terjadi gejala homoskedastisitas. Berikut hasil pengujian uji heteroskedastisitas disajikan pada Tabel 8.

Tabel 8.

Hasil Uji Heteroskedastisitas

\begin{tabular}{ll}
\hline \multicolumn{1}{c}{ Model } & Sig. \\
\hline Orientasi Kewirausahaan & .056 \\
\hline Inovasi Produk & .303 \\
\hline Sumber: data diolah, 2020
\end{tabular}

Sumber: data diolah, 2020

Berdasarkan Tabel 8 dapat disimpulkan bahwa tidak ada satupun variabel independen yang signifikan secara statistik mempengaruhi variabel dependen 
nilai absolut residual. Di mana terlihat bahwa probabilitas signifikansinya di atas tingkat keyakinan 5\%. Jadi dapat disimpulkan bahwa model regresi tidak mengandung adanya heteroskedastistas.

Tabel 9.

Koefisien Jalur I

\begin{tabular}{|c|c|c|c|c|c|}
\hline Model & $\mathbf{R}^{2}$ & Sig. F & Beta & $\mathbf{t}$ & Sig \\
\hline Orientasi & & & & & \\
\hline Kewirausahaan & .303 & .000 & .551 & 4.067 & .00 \\
\hline \multicolumn{6}{|c|}{ Sumber: data diolah, 2020} \\
\hline \multicolumn{6}{|c|}{ Persamaan Sub-struktural 1} \\
\hline \multicolumn{6}{|c|}{$\mathrm{M}=\beta_{2} \mathrm{X}+\mathrm{e}_{1} \ldots \ldots \ldots \ldots \ldots$} \\
\hline \multicolumn{6}{|c|}{$\mathrm{M}=0,551 \mathrm{X}+\mathrm{e}_{1}$} \\
\hline \multicolumn{6}{|l|}{ Standar Error } \\
\hline \multicolumn{6}{|l|}{$e_{1}=\sqrt{1}-R^{2}$} \\
\hline$e_{1}=\sqrt{1}-0,3$ & & & & & \\
\hline
\end{tabular}

Tabel 10.

Koefisien Jalur II

\begin{tabular}{llcll}
\hline Model & R2 & Beta & t & Sig. \\
\hline Orientasi &, 963 &, 006 &, 150 &, 882 \\
$\begin{array}{l}\text { Kewirausahaan } \\
\text { Inovasi Produk }\end{array}$ &, 000 &, 978 & 25,709 &, 000 \\
\hline
\end{tabular}

Sumber: data diolah, 2020

Persamaan Sub-struktural 2

$\mathrm{Y}=\beta_{1} \mathrm{X}+\beta_{3} \mathrm{M}+\mathrm{e}_{2}$

$\mathrm{Y}=0,006 \mathrm{X}+0,978 \mathrm{M}+\mathrm{e}_{2}$

Standar Error

$\mathrm{e}_{1}=\sqrt{1}-\mathrm{Ri}^{2}$

$e_{1}=\sqrt{1}-0,963=0,192$

Hasil koefisien jalur pada hipotesis penelitian dapat digambarkan pada Gambar 2. Berdasarkan diagram jalur pada Gambar 2 dapat dihitung besarnya pengaruh langsung, pengaruh tidak langsung serta pengaruh total antar variabel. Perhitungan antar variabel dirangkum pada Tabel 11.

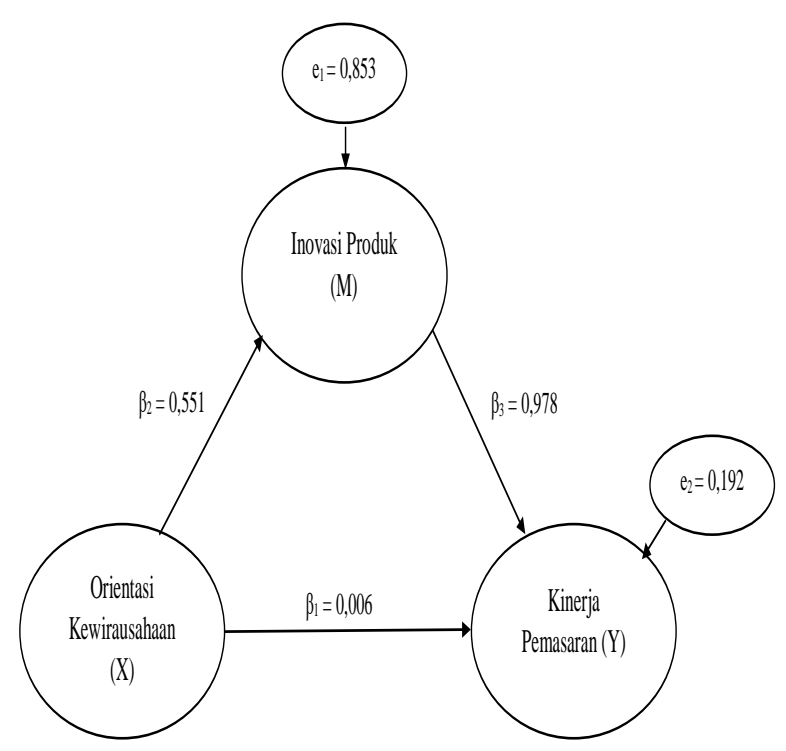

Gambar 2.

Validiasi Model Diagram Jalur

Pada Tabel 11 dipaparkan bahwa pengaruh langsung orientasi kewirausahaan terhadap kinerja pemasaran sebesar 0,006 sedangkan pengaruh orientasi kewirausahaan terhadap inovasi produk sebesar 0.551, pengaruh inovasi produk terhadap kinerja pemasaran sebesar 0.978. Sehingga dapat disimpulkan bahwa nilai sig t. 0,882>0,05 mengindikasikan bahwa $\mathrm{H}_{0}$ diterima dan $\mathrm{H}_{1}$ ditolak yang berarti orientasi kewirausahaan (X) berpengaruh positif tetapi tidak signifikan terhadap kinerja pemasaran (Y). Sedangkan pengaruh antar variabel orientasi kewirausahaan (X) terhadap inovasi produk (M) dan variabel inovasi produk (M) terhadap kinerja pemasaran (Y) adalah signifikan karena nilai sig t. $0,000 \leq 0,05$ mengindikasikan bahwa $\mathrm{H}_{0}$ ditolak dan $\mathrm{H}_{1}$ diterima. 
Peran Inovasi Produk Dalam Memediasi...

Desak Made Putriasih \& I Gusti Ayu Ketut Giantari

Tabel 11.

Hasil Uji Pengaruh Langsung, Pengaruh Tidak Langsung, dan Pengaruh Total

\begin{tabular}{lccc}
\hline Pengaruh Variabel & $\begin{array}{c}\text { Pengaruh } \\
\text { Langsung }\end{array}$ & $\begin{array}{c}\text { Pengaruh Tidak Langsung Melalui } \\
\text { Inovasi Produk }\left(\boldsymbol{\beta}_{\mathbf{2}} \mathbf{x} \boldsymbol{\beta}_{\mathbf{3}}\right)\end{array}$ & $\begin{array}{c}\text { Pengaruh Total } \\
\boldsymbol{\beta}_{\mathbf{1}}+\left(\boldsymbol{\beta}_{\mathbf{2}} \boldsymbol{x} \boldsymbol{\beta}_{\mathbf{3}}\right)\end{array}$ \\
\hline $\begin{array}{l}\text { Orientasi kewirausahaan } \rightarrow \text { Kinerja } \\
\text { Pemasaran }\end{array}$ & 0,006 & 0,539 & 0,545 \\
\hline $\begin{array}{l}\text { Orientasi kewirausahaan } \rightarrow \text { Inovasi } \\
\text { Produk }\end{array}$ & 0,551 & - & 0,551 \\
\hline $\begin{array}{l}\text { Inovasi produk } \rightarrow \text { Kinerja } \\
\text { pemasaran }\end{array}$ & 0,978 & - & 0,978 \\
\hline
\end{tabular}

Sumber: data diolah, 2020

Pengaruh tidak langsung dalam penelitian ini adalah orientasi kewirausahaan terhadap kinerja pemasaran melalui inovasi produk. Besarnya pengaruh tidak langsung adalah 0,539, dengan uji sobel mendapatkan nilai z sebesar 2,698; karena nilai z yang diperoleh sebesar 2,698 > 1,96 dengan tingkat signifikansi $5 \%$. Sehingga dapat disimpulkan bahwa bahwa inovasi produk mampu memediasi hubungan pengaruh orientasi kewirausahaan terhadap kinerja pemasaran secara positif dan signifikan. Pengaruh total hubungan antara variabel (X) terhadap (Y) melalui (M) sebesar 0.545. Nilai tersebut mengindikasikan adanya pengaruh yang signifikan.

Uji sobel merupakan alat analisis untuk menguji signifikansi dari hubungan tidak langsung antara variabel independen dengan variabel dependen yang dimediasi oleh variabel mediator. Uji sobel dirumuskan dengan persamaan berikut dan dapat dihitung dengan menggunakan aplikasi Microsoft Excel 2010. Bila nilai kalkulasi Z lebih besar dari 1,96 (dengan tingkat kepercayaan 95 persen), maka variabel mediator dinilai secara signifikan memediasi hubungan antara variabel terikat dan variabel bebas.
$Z=\frac{a b}{\sqrt{b^{2}} s_{a}^{2}+a^{2} s_{b}^{2}+s_{a}^{2} s_{b}^{2}}$

$Z=\frac{0,551 x 0,978}{\sqrt{0,978^{2}} 0,203^{2}+0,551^{2} 0,037^{2}+0,203^{2} 0,037^{2}}$

$\mathrm{Z}=2,698$

Dari hasil perhitungan uji sobel menggunakan persamaan 5, mendapatkan nilai $\mathrm{z}$ sebesar 2,698; karena nilai $\mathrm{z}$ yang diperoleh sebesar 2,698 > 1,96 dengan tingkat signifikansi $5 \%$ maka membuktikan bahwa inovasi produk (M) mampu memediasi hubungan pengaruh orientasi kewirausahaan (X) terhadap kinerja pemasaran (Y) pada UMKM Kuliner di Kabupaten Badung.

Berdasarkan pada hasil analisis jalur perngaruh $\mathrm{X}$ terhadap $\mathrm{Y}$, Nilai sig t. 0,882 > 0,05 mengindikasikan bahwa $\mathrm{H}_{0}$ diterima dan $\mathrm{H}_{1}$ ditolak yang berarti Orientasi Kewirausahaan (X) berpengaruh positif tetapi tidak berpengaruh signifikan terhadap Kinerja Pemasaran (Y). Berdasarkan hasil penelitian yang telah dilakukan, diperoleh hasil bahwa orientasi kewirausahaan (X) berpengaruh positif tetapi tidak berpengaruh signifikan terhadap kinerja pemasaran (Y) pada UMKM Kuliner di Kabupaten Badung, artinya ini 
menunjukkan bahwa orientasi kewirausahaan belum mampu memberikan pengaruh yang signifikan terhadap kinerja pemasaran pada UMKM kuliner di Kabupaten Badung.

Hasil penelitian ini mendukung hasil penelitian serupa sebelumnya yang pernah dilakukan pada penelitian yang menguji pengaruh orientasi kewirausahaa terhadap kinerja pemasaran. Penelitian yang dilakukan oleh Souisa (2018) menyatakan bahwa orientasi kewirausahaan tidak memiliki pengaruh yang signifikan terhadap kinerja pemasaran.

Berdasarkan pada hasil analisis jalur perngaruh $\mathrm{X}$ terhadap M, Nilai sig t. $0,000 \leq$ 0,05 mengindikasikan bahwa $\mathrm{H}_{0}$ ditolak dan $\mathrm{H}_{2}$ diterima yang berarti Orientasi Kewirausahaan $(\mathrm{X})$ berpengaruh positif dan signifikan terhadap Inovasi Produk (M). Nilai koefisien beta sebesar 0,551 menunjukkan arah positif (Hipotesis 2 terbukti). Berdasarkan hasil penelitian yang telah dilakukan, diperoleh hasil bahwa variabel orientasi kewirausahaan (X) berpengaruh positif dan signifikan terhadap variabel inovasi produk (M) pada UMKM Kuliner di Kabupaten Badung, artinya semakin meningkat orientasi kewirausahaan yang dimiliki pada UMKM kuliner di Kabupaten Badung maka inovasi produk pada UMKM kuliner di Kabupaten Badung akan semakin meningkat.

Hasil penelitian ini sejalan dengan penelitian sebelumnya yang dilakukan oleh Tresna \& Raharja (2019). Hasil penelitian sebelumnya yang menemukan pengaruh yang sama ialah penelitian yang dilaksanakan oleh Soekotjo et al., (2021). Maka penelitian tersebut dapat disimpulkan bahwa, inovasi produk perusahaan akan semakin meningkat apabila perusahaan tersebut mampu berani mengambil risiko kegagalan, proaktif dalam merespon keadaan pasar, antisipatif terhadap perubahan serta agresif dalam pencarian target pasar yang baru.

Berdasarkan pada hasil analisis jalur perngaruh $\mathrm{M}$ terhadap $\mathrm{Y}$, Nilai sig t. $0,000 \leq$ 0,05 mengindikasikan bahwa $\mathrm{H}_{0}$ ditolak dan $\mathrm{H}_{3}$ diterima yang berarti Inovasi Produk (M) berpengaruh positif dan signifikan terhadap Kinerja Pemasaran (Y). Nilai koefisien beta sebesar 0,978 menunjukkan arah positif (Hipotesis 3 terbukti). Berdasarkan hasil penelitian yang telah dilakukan, diperoleh hasil bahwa variabel inovasi produk (M) berpengaruh positif dan signifikan terhadap variabel kinerja pemasaran (Y) pada UMKM Kuliner di Kabupaten Badung, artinya semakin baik inovasi produk yang dimiliki pada UMKM kuliner di Kabupaten Badung maka kinerja pemasaran pada UMKM kuliner di Kabupaten Badung akan semakin meningkat.

Hasil penelitian ini didukung dengan penelitian sebelumnya yang dilakukan oleh Pramesti \& Giantari (2016). Hasil penelitian sebelumnya yang menemukan pengaruh yang sama ialah penelitian yang dilaksanakan oleh Efrata et al., (2019) menyatakan bahwa inovasi produk berpengaruh positif dan signifikan terhadap kinerja pemasaran, penelitian ini dilakukan pada industri kecil menengah. Maka dapat disimpulkan bahwa kinerja pemasaran perusahaan akan semakin meningkat apabila perusahaan tersebut mampu mengemas produk agar memiliki keunikan, mampu mengembangkan produk 
baru serta aktif melalukan pengembangan kualitas produknya.

Berdasarkan hasil penelitian yang telah dilakukan, diperoleh hasil bahwa inovasi produk mampu memediasi hubungan pengaruh orientasi kewirausahaan terhadap kinerja pemasaran pada UMKM Kuliner di Kabupaten Badung, artinya bahwa semakin baik penerapan orientasi kewirausahaan yang dimiliki pengusaha pada UMKM kuliner di Kabupaten Badung maka akan semakin meningkat kemampuan dalam berinovasi pada produk sehingga mampu meningkatkan kinerja pemasaran pada usaha kuliner di Kabupaten Badung. Hasil penelitian ini mendukung hasil penelitian serupa sebelumnya yang pernah dilakukan oleh Putri et al., (2018). Penelitian ini juga mendukung hasil penelitian yang dilakukan oleh Ryiadi \& Yasa (2016) yang menyatakan bahwa pada uji hipotesis yang dilakukan pada peran kemampuan inovasi memediasi pengaruh orientasi kewirausahaan terhadap kinerja produk, hal ini berarti orientasi kewirausahaan mampu meningkatkan kemampuan inovasi seorang wirausahawan serta mampu meningkatkan kinerja produk yang akan dihasilkan.

Terdapat dua hal yang mencakup implikasi hasil penelitian, yaitu implikasi teoritis dan implikasi praktis. Implikasi teoritis berkaitan dengan kontribusi hasil penelitian terhadap perkembangan teori mengenai peran inovasi produk dalam memediasi pengaruh orientasi kewirausahaan terhadap kinerja pemasaran. Sedangkan implikasi praktis berhubungan dengan kontribusi hasil penelitian terhadap peran inovasi produk dalam memediasi pengaruh orientasi kewirausahaan terhadap kinerja pemasaran pada UMKM kuliner di Kabupaten Badung. Hasil penelitian ini tidak mampu memperkaya teori strategi kinerja pemasaran yaitu orientasi kewirausahaan. Hasil penelitian telah mampu menunjukan hubungan yang tidak signifikan dari orientasi kewirausahaan terhadap kinerja pemasaran. Menunjukan hubungan yang positif dan signifikan dari hubungan orientasi kewirausahaa terhadap inovasi Produk, serta mampu menunjukan pengaruh inovasi produk dalam memediasi pengaruh orientasi kewirausahaan terhadap kinerja pemasaran. Maka penelitian ini telah mampu memperkaya penelitian sebelumnya, menambah kajian empiris serta mengkonfirmasi adanya hubungan orientasi kewirausahaan, inovasi produk dan kinerja pemasaran.

Berdasarkan hasil penelitian yang telah dilakukan maka untuk dapat meningkatkan kinerja pemasaran terkait kenaikan laba yang diperoleh perusahaan, angka penjualan yang meningkat dari periode sebelumnya. meluasnya jangkauan wilayah suatu pemasaran produk perusahaan serta tingkat pertumbuhan pelanggan perusahaan. dapat dilakukan dengan menerapkan strategi inovasi produk. Penerapan inovasi produk dapat dilakukan dengan mampu mengemas produk agar memiliki keunikan, mampu mengembangkan produk baru serta aktif melalukan pengembangan kualitas produknya.

Berdasarkan penelitian yang telah dilakukan terdapat beberapa keterbatasan dalam penelitian ini yaitu hanya dilakukan pada UMKM Kuliner yang berlokasi di 
Kabupaten Badung sehingga tidak dapat digeneralisasikan. Lingkungan yang dinamis dan selalu mengalami perubahan mungkin saja membuat adanya beberapa perubahan terkait dengan topik maupun hubungan serupa sehingga penelitian ini perlu dilakukan kembali dimasa mendatang.

\section{SIMPULAN DAN SARAN}

Orientasi kewirausahaan berpengaruh positif tetapi tidak signifikan terhadap kinerja pemasaran. Hal ini menunjukan bahwa sebuah usaha kuliner harus berani mengambil resiko dalam pengambilan keputusan untuk memberikan hasil yang lebih baik, jika orientasi kewirausahaan semakin baik maka akan mampu meningkatkan kinerja pemasaran. Orientasi kewirausahaan berpengaruh secara positif dan signifikan terhadap inovasi produk. Hasil ini menunjukan bahwa semakin baik penerapan orientasi kewirausahaan sebuah usaha kuliner, maka akan semakin baik juga kemampuan inovasi produknya. Inovasi produk berpengaruh positif dan signifikan terhadap kinerja pemasaran. Hasil ini menunjukan bahwa semakin baik penerapan inovasi produk sebuah usaha kuliner, maka akan semakin baik juga kemampuan kinerja pemasarannya. Inovasi produk secara positif dan signifikan mampu memediasi pengaruh orientasi kewirausahaan terhadap kinerja pemasaran. Hal ini menunjukan bahwa semakin baik penerapan orientasi kewirausahaan yang dimiliki pengusaha kuliner maka akan semakin meningkat kemampuan dalam berinovasi pada produk sehingga mampu meningkatkan kinerja pemasaran pada usaha kuliner di Kabupaten Badung.

Bagi pengusaha yang bergerak dalam bidang kuliner khususunya di Kabupaten Badung, agar lebih meningkatkan kemampuan dalam berinovasi di tengah persaingan dalam UMKM kuliner sehingga memiliki nilai tambah dimata konsumen. Dari segi orientasi kewirausahaan yang perlu ditingkatkan adalah pencarian target pasar baru, selain itu diharapkan bagi para wirusahawan agar lebih memperhatikan risiko yang dimiliki oleh usahanya, hal ini perlu dilakukan untuk mengakomodir risiko kegagalan, sehingga nantinya mampu meningkatkan kinerja pemasaran agar menjadi lebih baik dan akan menarik perhatian konsumen potensial serta mempertahankan konsumen yang sudah loyal. Untuk pihak pemerintah agar lebih baik apabila melakukan upaya pelatihan bagi pelaku usaha yang bergerak di bidang kuliner. Hal ini bertujuan agar pelaku usaha kuliner di Kabupaten Badung lebih berkualitas dan diharapkan mampu meningkatkan pertumbuhan ekonomi di Kabupaten Badung. Untuk peneliti selanjutnya agar dapat melakukan penelitian dengan menambah variabel seperti keunggulan bersaing, menambah jumlah sampel, serta memperluas jangkauan penelitian sehingga menyempurnakan penelitian selanjutnya.

\section{REFERENSI}

Back, Y., Parboteeah, K. P., \& Nam, D. (2018). Innovation in Emerging Markets: The Role of Consulting Firms. Academy of Management Proceedings, 2(1), 159-172. 
Peran Inovasi Produk Dalam Memediasi...

Desak Made Putriasih \& I Gusti Ayu Ketut Giantari

https://doi.org/https://doi.org/10.5465/ambpp. 2012.15972abstract

Badan Pusat Statistik. (2019). Statistik Kunjungan Wisatawan Mancanegara. Dalam Statistik Kunjungan Wisatawan Mancanegara 2015. Available at https://bali.bps.go.id/publication/2020/07/24/e 40b575f055874fc2eb05eee/statistikwisatawan-mancanegara-ke-bali-2019.html

Devara, K. S., \& Sulistyawati, E. (2019). Peran Inovasi Produk Dalam Memediasi Pengaruh Orientasi Pasar Terhadap Kinerja Pemasaran. E-Jurnal Manajemen Universitas Udayana, 8(10), 6367-6387. https://doi.org/https://doi.org/10.2 4843/ejmunud.2019.v08.i10.p25

Dinas Perdagangan dan Perindustrian Provinsi Bali. (2019). Akuntabilitas Kinjerja. Dalam Laporan Kinerja Instansi Pemerintah 2019. Available at https://disperindag.baliprov.go. id/wp-content/uploads/2020/06/LKJIP2019.pdf

Djayadiningrat, A. F., Sukaatmadja, I. P. G., \& Yasa, N. N. K. (2017). Peran Inovasi Produk Memediasi Orientasi Kewirausahaan terhadap Kinerja Pemasaran Imk Sektor Industri Makanan Kota Denpasar. E-Jurnal Manajemen Universitas Udayana, 6(9), 4978 - 5004. https://ojs.unud.ac.id/index.php/Manajemen/ar ticle/view/31680

Efrata, T. C., Radianto, W. E. D., Marlina, M. A. E., \& Budiono, S. C. (2019). The Impact of Innovation, Competitive Advantage, and Market Orientation on Firm's Marketing Performance in the Garment Industry in Indonesia. Advances in Economics, Business and Management Research, 100(1), 399-403. https://doi.org/10.2991/icoi-19.2019.68

Ejdys, J. (2016). Entrepreneurial Orientation vs. Innovativeness of Small and Medium Size Enterprises. Journal of Engineering, Project, and Production Management, 6(1), 13-24. https://doi.org/10.32738/jeppm.201601.0003

Fatoki, O. (2017). The Impact of Entrepreneurial Orientation on Access to Debt Finance and Performance of Small and Medium Enterprises in South Africa. Journal of Social Sciences, 32(2), 121-131. https://doi.org/https://doi.org/10.1080/097189 23.2012.11893058

Ibrahim, N. M. N., \& Mahmood, R. B. (2016). Factors influencing small and medium enterprises' performance. International Journal of
Economic, Commerce and Management, 4(1), 379-391. http://ijecm.co.uk/wpcontent/uploads/2016/01/4119.pdf

Lapian, A. A., James, M., \& Imelda, O. (2016). Pengaruh Orientasi Pasar dan Inovasi Produk Terhadap Kinerja Pemasaran pada PT. Prisma Dana Amurang. Jurnal EMBA, 6(2), 13301339.

https://ejournal.unsrat.ac.id/index.php/emba/ar ticle/view/12343

Nursini. (2020). Micro, small, and medium enterprises (MSMEs) and poverty reduction: empirical evidence from Indonesia. Development Studies Research, 7(1), 153-166. https://doi.org/10.1080/21665095.2020.18232 38

Okangi, F. P. (2019). The impacts of entrepreneurial orientation on the profitability growth of construction firms in Tanzania. Journal of Global Entrepreneurship Research, 9(1), 123. https://doi.org/10.1186/s40497-018-01431

Pertiwi, Y. D., \& Siswoyo, B. B. (2016). Pengaruh Orientasi Pasar Terhadap Kinerja Pemasaran Pada Umkm Kripik Buah Di Kota Batu. Syariah Paper Accouting FEB UMS, 1(1), 231-238.

https://publikasiilmiah.ums.ac.id/handle/1161 7/7332

Pramesti, N. M. V., \& Giantari, I. G. A. K. (2016). Peran Orientasi Pasar Memediasi Pengaruh Orientasi Kewirausahaan terhadap Kinerja UKM Industri Kerajinan Endek. E-Jurnal Manajemen Unud, 5(9), 5754-5782. https://ojs.unud.ac.id/index.php/Manajemen/ar ticle/view/23019

Putra, M. S. A., \& Setiawan, P. Y. (2019). Peran Inovasi Memediasi Orientasi Kewirausahaan Terhadap Kinerja Pemasaran Barbershop Di Kota Denpasar. E-Jurnal Manajemen Universitas Udayana, 8(11), 6804. https://doi.org/10.24843/ejmunud.2019.v08.i1 1.p21

Putri, M. A. L., Yasa, N. N. K., \& Giantari, I. G. A. K. (2018). Peran Inovasi Produk Memediasi Orientasi Pasar Terhadap Kinerja UKM Kerajinan Endek Di Kabupaten Klungkung. INOBIS: Jurnal Inovasi Bisnis Dan Manajemen Indonesia, 1(4), 522-534. https://doi.org/10.31842/jurnal-inobis.v1i4.56

Rezaei, J., \& Ortt, R. (2018). Entrepreneurial orientation and firm performance: the mediating role of functional performances. 
Peran Inovasi Produk Dalam Memediasi... Desak Made Putriasih \& I Gusti Ayu Ketut Giantari

Management Research Review, 41(7), 878900. https://doi.org/https://doi.org/10.110 8/MRR-03-2017-0092

Ryiadi, N. A., \& Yasa, N. K. (2016). Kemampuan Inovasi memediasi pengaruh Orientasi Kewirausahaan terhadap Kinerja Produk IMK Sektor Industri makanan di Kota Denpasar. EJurnal Manajemen Unud, 5(3), 1951-1941. https://ojs.unud.ac.id/index.php/Manajemen/ar ticle/view/18190

Santra, I. K. (2018). Entrepreneurial orientation and marketing performance of budget hotel smes in Bali Island. Journal of Legal, Ethical and Regulatory Issues, 22(4), 1-11. https://www.abacademies.org/articles/entrepre neurial-orientation-and-marketingperformance-of-budget-hotel-smes-in-baliisland-7727.html

Soekotjo, H., Cahyono, K. E., Nugroho, N. E., Rismawati, R., \& Kawiana, I. G. P. (2021). The role of mediation of product innovation in improving enterprises orientation of marketing performance of tofu industry. Management Science Letters, 11(1), 473-480. https://doi.org/10.5267/j.msl.2020.9.020

Souisa, W. (2018). The Effects of Entrepreneurial Orientation and Market Orientation on Business performance. Journal of Entrepreneurship Education, 21(4), 1-6. https://www.abacademies.org/articles/theeffects-of-entrepreneurial-orientation-andmarket-orientation-on-business-performance7470.html

Sulaeman, M. (2018). Pengaruh Orientasi Kewirausahaan, Orientasi Pasar, Dan Inovasi Produk Terhadap Kinerja Pemasaran (Studi Pada Industri Tahu Di Sentra Industri Tahu Kota Banjar). Jurnal Ilmiah Administrasi Bisnis Dan Inovasi, 2(1), 153-165. https://doi.org/10.25139/jai.v2i1.909

Tresna, P. W., \& Raharja, S. J. (2019). Effect of Entrepreneurial Orientation, Product Innovation and Competitive Advantage on Business Performance in Creative Industries in Bandung City, Indonesia. Review of Integrative Business and Economics Research, 8(3), 51-60. http://buscompress.com/uploads/3/4/9/8/3498 0536/riber_8-s3_05_t19-123_51-60.pdf

Utaminingsih, A. (2016). Pengaruh Orientasi Pasar, Inovasi, Dan Kreativitas Strategi Pemasaran Terhadap Kinerja Pemasaran Pada Ukm Kerajinan Rotan Di Desa Teluk Wetan,
Welahan, Jepara. Media Ekonomi Dan Manajemen, 31(2), 77-87. https://media.neliti.com/media/publications/14 9462-ID-pengaruh-orientasi-pasar-inovasidan-kre.pdf

Wibisono, T., Universari, N., \& Budiati, Y. (2020). Market Orientation, Entrepreneurship Orientation, and Company Performance: Study on Small and Medium Industries (Smes) Furniture in Demak District. Economics and Business Solutions Journal, 4(1), 20-35. https://doi.org/10.26623/ebsj.v4i 1.2240 